\title{
Assessment of Children with Primary Monosymptomatic Enuresis in Terms of Ambulatory Blood Pressure Changes
}

Özgün Araştırma Research Article

Received/Geliş: 02.12.2019 Accepted/Kabul: 11.02.2020

Published Online: 18.08 .2021

Demet Alaygut

Tepecik Eğitim ve Araştırma Hastanesi Çocuk Nefroloji Kliniği Izmir - Türkiye alaygutdemet@gmail.com ORCID: 0000-0002-2164-4652

H. Mertek 0000-0002-8237-4211 Tepecik Eğitim ve Araştırma Hastanesi Çocuk Sağlığı ve Hastalıkları Kliniği Izmir. Türkiye

E. Soyaltın 0000-0001-9744-7439 C. Alparslan 0000-0002-7046-8907 S.A. Çamlar 0000-0002-2402-0722 F. Mutlubaş 0000-0001-9392-4832

Ö. Yavaşcan 0000-0002-3582-5075 Tepecik Eğitim ve Araştırma Hastanesi Çocuk Nefroloji Kliniği Izmir - Türkiye

B.K. Demir 0000-0002-5456-3509 Izmir Katip Çelebi Üniversitesi Tıp Fakültesi Pediatrik Nefroloji Kliniği Izmir - Türkiye

This study was presented as a poster presentation at the $51^{\text {st }}$ Annual ESPN meeting.

Cite as: Mertek H. Alaygut D. Soyaltin E. Alparslan et al. Primer monosemptomatik enürezisli çocukların yaşam içi kan basıncı değişiklikleri açııından değerlendirilmesi. Tepecik Eğit. ve Araşt. Hast. Dergisi. 2021;31(2):148-53.

\author{
Primer Monosemptomatik Enürezisli Çocukların Yaşam \\ içi Kan Basıncı Değişiklikleri Açısından Değerlendirilmesi
}

\author{
Hilal Mertek $\odot$, Demet Alaygut $\odot$, Eren Soyaltın $\odot$, Caner Alparslan $\odot$, \\ Seçil Arslansoyu Çamlar ${ }^{\oplus}$, Fatma Mutlubaş ${ }^{\oplus}$, Önder Yavaşcan ${ }^{\oplus}$, Belde Kasap Demir ${ }^{\oplus}$
}

\begin{abstract}
Objective: To evaluate the relationship between blood pressure changes monitored by 24-hour blood pressure measurements and urinary incontinence in children with enuresis.

Method: The patients aged 5-18 years who received (patient group), and did not receive (control group) the diagnosis of primary monosymptomatic enuresis, and applied between January 01, 2017 and June 1, 2017, to the outpatient clinics of Izmir Tepecik Training and Research Hospital Department of Pediatric Nephrology and Pediatrics constituted the study group. Demographic data, height, body weight, body mass index, family history of chronic illness, and enuresis, drug use, laboratory test results (blood biochemistry and whole blood count) and ambulatory blood pressure monitoring (ABPM) measurements were compared between groups.

Results: Thirty-five (62.5\%, Group 1) patients and 21 (37.5\%, Group 2) control subjects were included in the study. Demographic properties of the patients were not remarkable. Family history of enuresis was detected in statistically significantly greater number of patients $(p=0.001)$. Any statistically significant difference was not noted when $A B P M$ data of both groups were compared.

Conclusion: Discrepancies in the results of various studies concerning the autonomic system changes in enuretic patients, their reflections on blood pressures, and 24-hour blood pressure profiles, in addition to controversial views of the authors about relationship between decreasing urine output and BP depression have necessitated conduction of further studies with larger group of patients.
\end{abstract}

Keywords: Primary enuresis, blood pressure changes, ambulatory blood pressure

\section{öz}

Amaç: Enürezisli çocuk hastalarda 24 saatlik kan basıncı ölçümü yapılarak kan basıncı değişikliği ile gece idrar kaçırma arasındaki ilişkinin araştııılması.

Yöntem: Ocak 2017-Haziran 2017 tarihleri arasında Sağlık Bilimleri Üniversitesi Izmir Tepecik Eğitim ve Araștırma Hastanesi Çocuk Nefroloji ve Çocuk Dahiliye polikliniklerine başvuran 5-18 yaş arası primer monosemptomatik enürezis tanııı alan olgular ve benzer yaşda olup sağlıklı çocuk izleminde olan gönüllü hastalar kontrol grubu olarak, etik kurul onayı da alınarak çalışmaya dahil edilmiştir. Hastaların demografik bilgileri, boy, vücut ağırlığı, vücut kitle indeksleri, ailede kronik hastalık ve enürezis öyküsü, ilaç kullanımı, laboratuvar tetkikleri (kan biyokimyası ve tam kan sayımı) ve yaşam içi kan basıncı izlemi (YiKBi) ölçümleri karşılaştırılmıştır.

Bulgular: Çalıșmaya 35 hasta (\%62,5, grup 1) ve 21 kontrol grubu (\%37,5, grup 2) dahil edildi. Her iki grubun cinsiyet ve vücut kitle indeksleri karşılaş̧ırıldığında, anlamlı bir fark bulunmadı. Ancak yaş $(p=0,040)$, vücut ağırlığı $(p=0,042)$ ve boy $(p=0,031)$ istatistiksel olarak anlamlıydı. Geçmiş öyküsü ve aile öyküsü verileri incelendiğinde, ailede enürezis öyküsü varlığı hasta grubunda istatistiksel olarak anlamlıydı ( $p=0,001)$. Her iki grubun ABPM verileri karşılaştırıldığında, istatistiksel olarak anlamlı bir fark yoktu.

Sonuç: Sonuç olarak enürezisli hastalarda otonom sistem değişikliklerini ve bunun kan basıncı üzerine yansımalarını tespit etmek amacı ile yapılan bu çalışmada bunu destekleyecek anlamlı veri elde edilememiştir. Daha büyük sayıdaki hasta gruplarında yapılacak çalışmalara ihtiyaç duyulmaktadır.

Anahtar kelimeler: Primer enürezis, kan basıncı değişikliği, yaşam içi kan basıncı
(C) Telif hakkı TC. Să̆lkk Bakanlı̆̆ı İzmir Tepecik Eğit. ve Arast. Hastanesi. Logos Tip Yayınclık tarafindan yayınlanmaktadır. Bu dergide yayınlanan bütün makaleler Creative Commons Attf-GayriTicari 4.0 Uluslararası Lisansı ile lisanslanmıştr. (c) Copyright Association of Publication of the T.C. Ministry of Health Izmir Tepecik Education and Research Hospital. This journal published by Logos Medical Publishing.

Licenced by Creative Commons Attribution-NonCommercial 4.0 International (CC BY) 


\section{INTRODUCTION}

Enuresis is urinary incontinence of a child, who is at least $\geq 5$ years old and has bladder control during sleep (1). Due to its high prevalence, controversial etiology and differences in its treatment among children, it is a frequently emphasized subject ${ }^{(2)}$. It is seen in the rate of $5-10 \%$ at the age of 7 and $0.5-1 \%$ in adulthood ${ }^{(3)}$. It is more common in boys than girls but this difference tends to decrease after the age of 10. This benign disorder usually disappears with age. Besides, if it is not treated, especially those with severe enuresis remain enuretic ${ }^{(4)}$. Enuresis is divided into two categories as monosymptomatic and nonmonosymptomatic groups. Monosymptomatic enuresis is a type of enuresis without concomitant urinary dysfunction. Urination, like many bodily functions, has a circadian rhythm. The expected result is decreased urination during sleep. At night, this condition is also accompanied by a decrease in arterial blood pressure (BP) ${ }^{(5)}$. Blood pressure also has a circadian rhythm. Arterial blood pressure decreases during sleep. This decrease varies from person to person. In healthy individuals, the arterial blood pressure at night is approximately $10 \%$ lower than the mean arterial blood pressure measured during the day. This phenomenon is called the "dipping" phenomenon ${ }^{(6)}$.

Hypertension (HT) in children refers to the mean systolic and/diastolic blood pressure that is $\geq 95$ percentile higher than gender, age and heightadjusted BP values measured at least three different occasions (7). Only a single BP measurement overestimates HT prevalence in children. Difficulties and inconsistencies observed in terms of BP measurements complicate evaluation of hypertensive patients. Thanks to ambulatory blood pressure monitoring (ABPM), BP measurements of the patient are performed in his/her own environment throughout the day, and as a consequence reliable and permanent records and statistical results can be obtained ${ }^{(8)}$.

The aim of this study was to investigate the correlation between the blood pressure changes and enuresis by performing 24 -hour blood pressure monitoring in children with enuresis.

\section{MATERIAL and METHOD}

This study was planned and conducted in the Nephrology Department of Pediatric Clinic of Izmir Tepecik Training and Research Hospital of University of Health Sciences. Ethics Committee approval was obtained (25.02.2016/17) was obtained from the Noninvasive Clinical Trials Ethics Committee of Izmir Katip Çelebi University. The study was conducted as a single center trial in Izmir Tepecik Training and Research Hospital between 01 January 2017 and 01 June 2017. Among patients aged between $5-18$ years who applied to outpatient clinics of Pediatric Nephrology and Internal Medicine, children who were diagnosed with primary monosymptomatic enuresis constituted the patient, while the patients who had not primary monosymptomatic nocturnal enuresis consisted the control group. Demographic information, height, body weights, body mass indexes, family history of chronic disease, and enuresis, drug use, and also laboratory test (blood biochemistry and whole blood count) and ambulatory blood pressure monitoring (ABPM) results of the study participants were recorded.

While the patient group consisted of enuretic patients aged between 5-18 years without renal pathology and additional systemic disease affecting the kidney, the control group consisted of the age, and gendermatched patients without enuretic symptoms and additional systemic disease. Volunteers who did not meet these criteria or could not comply with the ambulatory blood pressure monioring device were excluded from the study.

Statistical analysis was performed using SPSS version 24 software. The suitability of the variables to normal distribution was examined by KomogorovSmirnov/Shapiro-Wilk tests. Descriptive analyses were expressed as mean and standard deviations for normally distributed variables. Since normal 
distribution of variables was ensured for patient and control groups, the measurements obtained from these groups were analyzed using independent groups t-test. Chi-square and Fisher's exact tests were applied in the comparison of binary ratios. $P$ values of $<0.05$ were evaluated as statistically significant.

\section{RESULTS}

A total of 56 patients including 35 individuals in the patient (Group 1) (62.5\%) and 21 individuals in the control (Group 2) (37.5\%) group were enrolled in the study. There were 12 girls (34\%) and 23 boys (66\%) in Group 1 and 11 girls (52\%) and 10 boys (48\%) in Group 2.

The mean ages of the study participants were determined as $114.9 \pm 21.3(75-154)$, and $123.7 \pm 27.2$ (80-171) months in Groups 1, and 2, respectively with a statistically significant difference between the mean ages of both groups ( $p=0.04)$.

The mean body weights of study participants were $35 \pm 14.6 \mathrm{~kg}(17-70)$ and $36.4 \pm 14.6 \mathrm{~kg}(21-71)$ in

Table 1. Demographic properties of patients.

\begin{tabular}{lccc}
\hline & $\begin{array}{c}\text { Group 1 } \\
\mathbf{N}=\mathbf{3 5}\end{array}$ & $\begin{array}{c}\text { Group 2 } \\
\mathbf{N = 2 1}\end{array}$ & $\mathbf{p}$ \\
\hline Gender & $\mathrm{F}: 12(34 \%)$ & $\mathrm{F}: 11(52 \%)$ & 0.263 \\
Age & $114.9 \pm 21.3$ & $\mathrm{M}: 10(48 \%)$ & 0.040 \\
Weight $(\mathrm{kg})$ & $35.0 \pm 14.6$ & $38.4 \pm 14.6$ & 0.235 \\
Height $(\mathrm{cm})$ & $135.7 \pm 13.5$ & $136.2 \pm 12.1$ & 0.276 \\
Body mass index & $18.3 \pm 4.9$ & $19.7 \pm 4.2$ & \\
\hline
\end{tabular}

Table 2. Chronic disease. family histories. drug use and enuresis in family.

\begin{tabular}{lcccc}
\hline & & Group 1 (n) & Group 2 (n) & p \\
\hline Chronic disease in patient & No & 32 & 21 & 0.284 \\
& Yes & 3 & 0 & \\
\hline Drug use & No & 34 & 21 & 1.000 \\
& Yes & 1 & 0 & \\
\hline Chronic disease in family & No & 34 & 21 & 1.000 \\
& Yes & 1 & 0 & \\
\hline Enuresis in family & No & 22 & 21 & 0.001 \\
& Yes & 13 & 0 & \\
& & & &
\end{tabular}

Groups 1 and 2, respectively. Mean heights of study participants in Groups 1, and 2 were 135.7 $\mathrm{cm} \pm 13.5$ (106-170), and $136.2 \pm 12.1 \mathrm{~cm}$ (128-169), respectively. Mean body mass indices in Groups 1, and 2 were $18.3 \pm 4.9$ (12-33) and 19.7 \pm 4.2 (13-28), respectively.

There was no significant difference between groups as for demographic data Data concerning age, gender, body mass, height and body mass indices of Groups 1 and 2, are seen in Table 1. Chronic disease, drug use, family history of chronic disease and enuresis were not found in the control group; however familial Mediterranean fever $(n=2 ; 6 \%)$, obesity in $=1)$, colchicine use $(n=1 ; 3 \%)$, family history of chronic disease (vesicoureteral reflux, $n=1 ; 3 \%$ ), and enuresis $(n=13 ; 37 \%)$ were detected in the patient group as seen in Table 2. Table 3 shows results of evaluation of tubular tests. In ABPM assessment, no difference was found between average daytime, and nighttime systolic and diastolic values. Also, there was no difference between the groups in terms of daytime, and nighttime systolic and diastolic values exceeding the limit values. The 24-hour mean systolic and diastolic blood pressure values were higher in the control group. While there was no difference between the groups in terms of average daytime, nighttime

Table 3. Tubular tests of patients.

\begin{tabular}{lccc}
\hline & Group 1 & Group 2 & $\mathbf{p}$ \\
\hline Density & $1019.9 \pm 7.1$ & $1018 \pm 8.1$ & 0.374 \\
pH & $6.0 \pm 0.6$ & $5.9 \pm 0.4$ & 0.370 \\
FeNa & $0.62 \pm 0.37$ & $0.50 \pm 0.27$ & 0.146 \\
FeK & $11.48 \pm 5.89$ & $9.99 \pm 6.98$ & 0.252 \\
TPR & $92.93 \pm 3.43$ & $92.50 \pm 4.34$ & 0.698 \\
Pro/ crea & $0.09 \pm 0.03$ & $0.08 \pm 0.04$ & 0.294 \\
Ca /crea & $0.06 \pm 0.08$ & $0.06 \pm 0.04$ & 0.575 \\
\hline
\end{tabular}

Table 4. Blood pressures measurement of patients.

\begin{tabular}{lccc}
\hline & Group 1 & Group 2 & $\mathbf{p}$ \\
\hline 24 hours mean systolic pressure & $103.6 \pm 7.7$ & $107.5 \pm 5.08$ & 0.029 \\
24 hours mean diastolic pressure & $60.3 \pm 6.7$ & $63.4 \pm 4.3$ & 0.041 \\
Day mean arteriel pressure & $83.05 \pm 7.39$ & $85.7 \pm 4.1$ & 0.085 \\
Night mean arteriel pressure & $75.5 \pm 5.89$ & $79.0 \pm 6.57$ & 0.057 \\
24 hours mean arteriel pressure & $80.1 \pm 6.7$ & $83.5 \pm 4.1$ & 0.021 \\
ABPM day SDS & $0.24 \pm 1.1$ & $0.72 \pm 0.6$ & 0.184 \\
ABPM night SDS & $0.95 \pm 0.77$ & $1.3 \pm 1.04$ & 0.196 \\
ABPM 24 hours SDS & $0.10 \pm 1.0$ & $0.5 \pm 0.63$ & 0.072 \\
& & & \\
\hline
\end{tabular}


and 24-hour arterial BP values. Similarly, standard deviation scores (SDSs) were not also different between groups in terms of daytime, nighttime and 24-hour ABPM measurements (Table 4). Decreases in systolic and diastolic blood pressures were determined as $7.2 \pm 4.3 \%(0.1-15.3)$ vs $7.2 \pm 4.6 \%$ (0.6$19.3)$ and $13.1 \pm 5.7 \%(2.6-24.2)$ vs $13.2 \pm 6.8 \%(2.6-$ $26.1)$ in Groups 1 , and 2 , respectively $(p=0.936)$.

The mean daytime heart rates were $86.3 \pm 8.1 \mathrm{bpm}$ in Group 1, and $88.8 \pm 12.5$ bpm in Group 2. While nighttime heart rates were $70.8 \pm 8.1 \mathrm{bpm}$ in Group 1 $(p=0.033)$, and $76.8 \pm 10.4(p=0.033)$ in Group 2 .

\section{DISCUSSION}

In this study, we have tried to make the pathogenetic role of autonomic nervous system in the pediatric enuresis more understandable and evaluate it based on ambulatory blood pressure measurements. For this purpose, as an easily accessible, and noninvasive test, 24-hour blood pressure monitoring was applied to the patient and control groups.

Nocturnal enuresis is more common in boys than in girls (60\%/40\%). In accordance with the literature in this study group, more than half of the study population (66\%) consisted of enuretic boys. Besides, when compared with the control group, significantly greater number of patients had a family history of enuresis. which was also compatible with the literature ${ }^{(9)}$.

Only serum creatinine levels were found to be higher in the control group which also complied with the literature findings.

Some studies have suggested that increased nocturnal sodium excretion plays a role in patients with nocturnal polyuria. Abnormalities in serum sodium value or fractional sodium excretion during daytime may cause BP changes in the patients included in this study. However, sodium excretion at night could not be examined, and nocturnal urinary excretion could not be measured. Other tubular tests were normal in both groups and any solute excretion load was not encountered. In their study Kahraman $A$ et al. ${ }^{(9)}$, found that the serum sodium concentration was higher in the enuretic group with a lower blood pressure difference between daytime and nighttime measurements.

As a result of the evaluation based on ABPM measurements, any hypertensive patients were not detected in both groups. Systolic and diastolic blood pressure values exceeding the limit values were below $25 \%$ in both groups. Mean daytime, nighttime and 24-hour total systolic and diastolic blood pressure values, ABPM measurements, SDSs, and dipping phenomena were evaluated. Any statistically significant difference was not found between the two groups as for these parametres.

Conflicting results were reported in few studies conducted on the evaluation of autonomic nervous system in enuretic patients. In fact, some researchers believed that enuresis is a condition associated with immaturation and/or delayed maturation of autonomic nervous system. This view is also supported by the theory of vegetative infantilism ${ }^{(10)}$. In addition, although the decline in the incidence of enuresis with the advanced age has been thought to support this developmental progress, this condition was believed to be associated with the autonomic nervous system dysfunction rather than autonomic nervous system immaturity ${ }^{(11)}$. Various studies using different methods have been planned for this purpose. While some studies showed that parasympathetic activity increased in enuretics, some others demonstrated the contrary ${ }^{(12,13)}$. Dundaröz et al. ${ }^{(14)}$, found that the dominant activity was associated with sympathetic nervous system in enuretic patients. In addition, they speculated that this condition would explain why some enuretic patients did not respond to anticholinergics.

There are limited number of studies evaluating the correlations between hormonal rhythm, urination and blood pressure changes. The most comprehensive study on this subject was conducted by Rittig et al. ${ }^{(15)}$. 
They evaluated the circadian rhythm, BP changes, and urination in association with renin, angiotensin and aldosterone levels in enuretic patients. Increase in aldosterone and angiotensin II levels was demonstrated during sleep in the patient group compared to the control group and a significant intergroup difference was found in terms of diurnal / nocturnal urine output and sodium excretion. This difference could not be shown in the patient group and tried to be explained with the impaired hormonal circadian rhythm ${ }^{(15)}$. A study in which 24 -hour blood pressure measurements were performed in enuretics showed that enuretic patients were non-dipper hipertensives and had higher nocturnal SBP and DBP values. Besides, any significant correlation was not found between the mean SBP, DBP, MAP and aldosterone/renin levels ${ }^{(9)}$. In the present study, the difference between mean SBP and 24-hour MAP values of patients in the control group was not statistically significant. It was thought that this condition was associated with the fact that the patients in the control group were taller than the patient group.

In the evaluation of heart rate values that are indicators of sympathetic hyperactivity, it was found that although the daytime and nighttime heart rate values were higher in the control group than enuretic group ( $p=0.033)$, mean 24 -hour heart rate values did not differ between groups. This lack of difference suggested the presence of white-coat hypertension in the control group. In their study, Yuce $O$ et al. ${ }^{(16)}$, evaluated 28 patients with monosymptomatic enuresis aged between 6-15 years based on 24-hour blood pressure measurements and found higher heart rates in enuretics which they thought to be probably related to increased arterial baroreceptor reflex responses. Normally, increased arterial pressure stimulates arterial baroreceptors in the aortic arch and carotid sinus area which leads to reflex inhibition of sympathetic efferent nerve activity and a decrease in heart rate with increased stimulation of parasympathetic efferent nerve activity.
Regulation of circadian BP in enuretic patients is a challenging task. Selective increases in nocturnal SBP, DBP and MAP and decreased nocturnal dipping are indicators of sympathetic hyperactivity. Dysfunction of autonomic activity may play an important role in the pathogenesis of enuresis. It can be speculated that the alterations in circadian rhythm induced by the hormonal activity in autonomic dysfunction is one of the key points in the pathogenesis of enuresis. In order to better reveal this assumption, studies with larger groups demonstrating the correlation between BP dysregulation, hormonal circadian rhythm and enuresis should be conducted.

Kruse A et al. (17), evaluated nocturnal blood pressure values and their relationship with urination in 39 monosymptomatic enuretic children with an average age of 9.8 years, and recorded higher nighttime mean blood pressure values in the group with nocturnal polyuria when compared with healthy controls without polyuria. In addition, a positive correlation was found between the nocturnal urination and nocturnal mean blood pressure values. However, when dry and wet nights were compared, any difference was not found between the mean arterial pressure values. In the present study, we found higher 24-hour MAP values in the control group which did not support our hypothesis.

Nocturnal dipping in arterial blood pressure may appear as a part of normal circadian rhythm. The absence of this condition is called as "non-dipping" phenomenon. Although the exact reason of the decrease in nocturnal blood pressure was not fully understood, some results suggest the presence of some alterations in autonomic nervous system activities (such as abnormal parasympathetic and increased sympathetic nervous system activity) of non-dipper patients. In the study conducted by Kahraman A et al. ${ }^{(9)}$ with a total of 45 enuretic children, mean systolic and diastolic dipping values of the patients were found to be lower than those of the control group and enuretic patients were thought to have episodes of non-dipper hypertension more frequently. In our study group, decreases in systolic 
blood pressures of both enuretic and control groups were more marked compared to decreases in diastolic BPs but without any significant intergroup difference.

As limitations of the present study, nocturnal urine volumes and hormone (renin/aldosterone, ANP, etc.) levels during sleep could not be evaluated. It was believed that difference between the patient and the control groups in terms of weight and height of the study participants caused an increase in serum creatinine, heart rate and 24-hour MAP values in favor of the control group. In addition, another limitation is the small number of cases in the patient group.

Consequently, study results about alterations in the autonomic system and their reflections on BP in enuretic patients differ widely. Generally, 24-hour blood pressure profiles are quite different from each other. The assumption that urination is dependent on circadian rhythm and will decrease during sleep in association with concurrent decrease in BP has been supported or rejected by different authors. Therefore, further studies with greater number of patients should be realized concerning this issue.

Ethics Committee Approval: İzmir Katip Çelebi University Faculty of Medicine Clinical Research Ethics Committee approval was obtained (25.02.2016/17).

Conflict of Interest: The authors certify that there is no conflict of interest with any financial organization regarding the material discussed in the manuscript.

Funding: None.

Informed Consent: Receipt.

\section{REFERENCES}

1. Neveus T, von Gontard A, Hoebeke P, Hjalmas K, Bauer S, Bower W, Jørgensen TM, Rittig S, Walle JV, Yeung CK, Djurhuus JC. The standardization of terminology of lower urinary tract function in children and adolescents: report from the Standardisation Committee of the International Children's Continence Society. J Urol. 2006;176:314-24. [CrossRef]

2. Von Gontard A, Lettgen B, Olbing H, Heiken-Löwenau C,
Gaebel E, Schmitz I. Behavioural problems in children with urge incontinence and voiding postponement. A comparison of a paediatric and child psychiatric sample. $\mathrm{Br} \mathrm{J}$ Urol. 1998;81(suppl 3):1006. [CrossRef]

3. Butler RJ, Golding J, Northstone K. Nocturnal enuresis at 7.5 years old: prevalence and analysis of clinical signs. BJU Int. 2005;96:404-10. [CrossRef]

4. Yeung CK, Sihoe JDY, Sit FKY, Bower W, Sreedhar B, Lau J Characteristics of primary nocturnal enuresis in adults: an epidemiological study. BJU Int. 2004;93:341-5. [CrossRef]

5. Kruse A, Mahler B, Rittig S, Djurhuus JC Increased nocturnal blood pressure in enuretic children with polyuria. J Urol 2009 182:1954-1960. Graugaard-Jensen C, Rittig S, Djurhuus JC Nocturia and circadian blood pressure profile in healthy elderly male volunteers. J Urol. 2006;176:1034-9. [CrossRef]

6. O'Brien E Dipping comes of age: the importance of nocturnal blood pressure. Hypertension 2009; 53:446-447. Sayk F, Becker C, Teckentrup C, Fehm HL, Struck J, Wellhoener JP, Dodt C To dip or not to dip: on the physiology of blood pressure decrease during nocturnal sleep in healthy humans. Hypertension. 2007;49:1070-6. [CrossRef]

7. Candan C, Çalışkan S. Çocukluk çağında hipertansiyona yaklaşım. Derleme. Türk Pediatri Arşivi. 2005;40:15-22.

8. McNiece KL, Portman RJ. Hypertension: Epidemiology and evaluation. Kher KK, Schnaper HW, Makker SP. Clinical pediatric nephrology. UK: Informa Healthcare. 2007; 461-80. [CrossRef]

9. Kahraman A, Dursun H, Hatipoglu S, Kural B, Sahin M, Birgul $\mathrm{K}$, Akyol MB, Non-dipping phenomenon in children with monosymptomatic nocturnal enuresis. Pediatr Nephrol. 2013;28:1099-1103. [CrossRef]

10. Popov I. Autonomic infantilism .Med Pregl. 1982;42:41-4.

11. Forsythe WI, Redmond A. Enuresis and spontaneous cure rate. Study of 1129 enuretis. Arch Dis Child. 1974;49:259263., Fergusson DM, Horwood LJ, Shannon FT. Factors related to the age of attainment of nocturnal bladder control: An 8-year longitudinal study. Pediatrics. 1986;78:88490.

12. Unalacak M, Aydin M, Ermis B, Ozeren A, Sogut A, Demirel F, Unluoğlu I, Assessment of cardiac autonomic regulation in children with monosymptomatic nocturnal enuresis by analysis of heart rate variability. Tohoku J Exp Med. 2004;204:63-9. [CrossRef]

13. Dundaroz R, Turkbay T, Erdem U, Congologlu A, Sakallıoğlu O, Tascilar E, Pupillometric assessment of autonomic nervous system in children with functional enuresis. Int Urol Nephrol. 2009;41:231-5. [CrossRef]

14. Dundaroz MR, Denli M, Uzun M, Aydın HI, Sarıcı SU, Yokuşoğlu $M$, Ülgen $S$. Analysis of heart rate variability in children with primary nocturnal enuresis. Int Urol Nephrol. 2001;32:393-7. [CrossRef]

15. Rittig S, Matthiesen TB, Pedersen EB, Djurhuus JC. Circadian variation of angiotensin $\mathrm{II}$ and aldosterone in nocturnal enuresis: relationship to arterial blood pressure and urine output. J Urol. 2006;176:774-80. [CrossRef]

16. Yüce O, Bayrakçi US, Gülleroğlu K, Baskın E. Abnormal circadian blood pressure regulation in children with nocturnal enuresis, Renal Failure. 2016;38:899-905. [CrossRef]

17. Anne Kruse, Birgitte Mahler, Soren Rittig Jeans Christian Djurhuus. Increased Nocturnal Blood Pressure in Enuretic Children with Polyuria The J of Urol. 2009;182:1954-60. [CrossRef] 